\title{
ARCHAEOLOGY AND PUBLIC PERCEPTION \\ OF A TRANSSCIENTIFIC PROBLEM- \\ DISPOSAL OF TOXIC WASTES IN \\ THE UNSATURATED ZONE
}

U.S. GEOLOGICAL SURVEY CIRCULAR 990

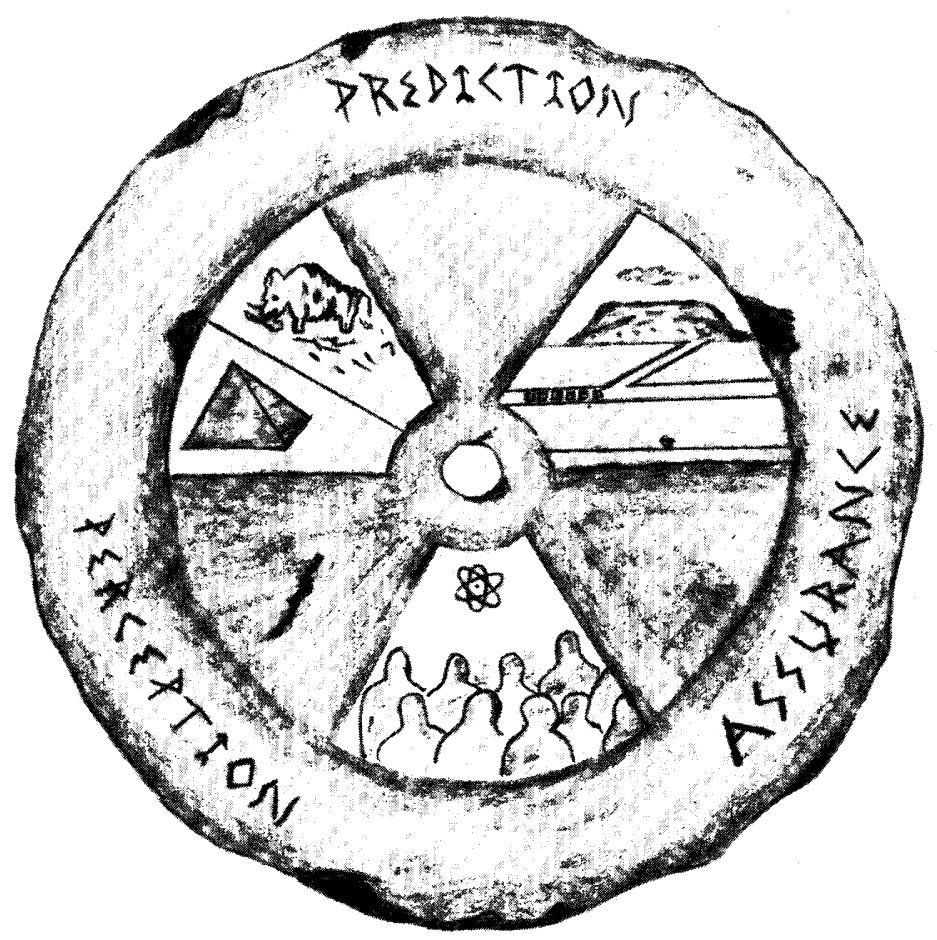





\section{ARCHAEOLOGY AND PUBLIC PERCEPTION OF A TRANSSCIENTIFIC PROBLEM- DISPOSAL OF TOXIC WASTES IN THE UNSATURATED ZONE}

By Isaac J. Winograd

U.S. GEOLOGICAL SURVEY CIRCULAR 990 


\title{
DEPARTMENT OF THE INTERIOR DONALD PAUL HODEL, Secretary
}

\section{U.S. GEOLOGICAL SURVEY}

\author{
Dallas L. Peck, Director
}

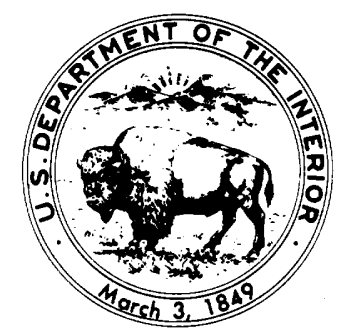

Library of Congress Cataloging-in-Publication Data

Winograd, Isaac Judah, 1931-

Archaeology and public perception of a transscientific problem.

(U.S. Geological Survey circular ; 990)

Bibliography: p. 8

Supt. of Docs. no.: I 19.4/2:990

1. Hazardous wastes-Environmental aspects. 2. Hazardous waste sites-Environmental aspects. 3. Environmental archaeology. I. Title. II. Series.

TD811.5.W56 1986

$363.7^{\prime} 28$

86-600356

Free on application to the Books and Open-File Reports Section, U.S. Geological Survey, Federal Center, Box 25425, Denver, CO 80225 


\section{CONTENTS}

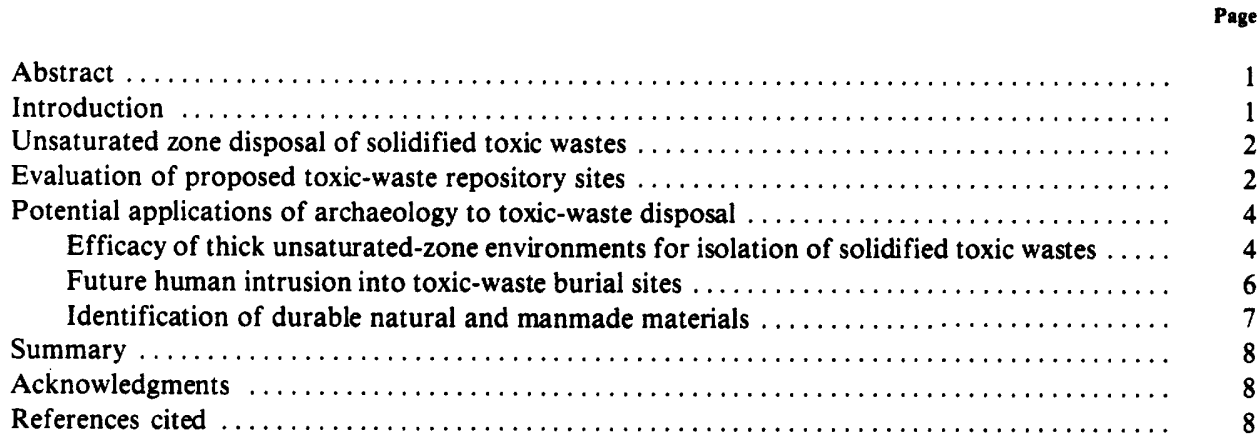





\title{
Archaeology and Public Perception of a Transscientific Problem-Disposal of Toxic Wastes in the Unsaturated Zone
}

\author{
By Isaac J. Winograd
}

\begin{abstract}
Predicting the effects of toxic-waste disposal on the environment over periods of millenia to hundreds of millenia is a transscientific problem; that is, one not fully addressed by quantitative scientific and engineering endeavors. Archaeology is a pertinent adjunct to such predictions in several ways. First, and foremost, archaeological records demonstrate that delicate, as well as durable, objects buried in thick unsaturated zones of arid and semiarid environments may survive intact for millenia to tens of millenia. This successful preservation of Late Paleolithic to Iron Age artifacts provides independent support for the tentative favorable conclusions of earth scientists regarding the general utility of thick unsaturated zones for toxic-waste isolation. By analogy with the archaeological record, solidified toxic wastes of low solubility that are buried in arid unsaturated zones should remain isolated from the environment indefinitely; modern man presumably should be able to improve upon the techniques used by his ancestors to isolate and preserve their sacred and utilitarian objects. Second, archaeological evidence pertinent to the fate of objects buried in unsaturated zones - although qualitative in nature and subject to the limitations of arguments by analogy - is meaningful to the public and to the courts who, with some scientists and engineers, are reluctant to rely exclusively on computer-generated predictions of the effects of buried toxic wastes on the environment. Third, the archaeological record issues a warning that our descendants may intrude into our waste disposal sites and that we must therefore take special measures to minimize such entry and, if it occurs, to warn of the dangers by a variety of symbols. And fourth, archaeology provides a record of durable natural and manmade materials that may prove to be suitable for encapsulation of our wastes and from which we can construct warning markers that will last for millenia. For these four reasons, archaeologists must join with earth scientists, and other scientists and engineers, in addressing the likely fate of solidfied toxic wastes buried in the thick (200-600 m) unsaturated zones of arid and semiarid regions. Indeed, the input of archaeology might be crucial to public acceptance of even the most carefully chosen and technically sound waste repository.
\end{abstract}

\section{INTRODUCTION}

Alvin Weinberg (1985) used the term transscientific to describe certain environmental problems that, while requiring the close attention of scientists and engineers, are not likely to be solved by science. For example, in matters such as unraveling the health effects of low-level ionizing radiation - in an environment containing numerous other potential mutagens and carcinogens - Weinberg (1985) suggested that both the general public and governmental regulators might have to lower their expectations for quantitative answers from science and engineering. The disposal of certain highly toxic wastes, such as highlevel radioactive waste, is another transscientific issue. Earth scientists, in collaboration with chemical engineers, material scientists, and others, are being called upon to predict the environmental fate of highlevel radioactive wastes for periods of millenia to hundreds of millenia. Such predictions-to be generated by complex mathematical models that synthesize knowledge from numerous disciplines - are of necessity tenuous because a data base with which to calibrate such models does not now exist, nor is it likely to exist prior to the filling and sealing of the first waste repository. Simply put, we do not have the geotechnical experience with which to evaluate the reliability of model predictions even for centuries. The time dimension, alone, relegates high-level radioactive waste disposal to the realm of transscientific issues.

This paper was written to suggest that, while quantitative analysis of the fate of buried toxic wastes is unlikely, by itself, to prove adequate, highly pertinent qualitative evidence bearing on this complex matter resides in the field of archaeology. Such evidence may enable the scientist, the regulator, and the general public to convince themselves that solidified toxic wastes may be safely disposed of in carefully selected underground environments, even in the absence of quantitative proof. The author hopes 
that this paper will generate interest among archaeologists in applying their knowledge to the burgeoning, global, transscientific problems of toxicwaste disposal.

\section{UNSATURATED ZONE DISPOSAL OF SOLIDIFIED TOXIC WASTES}

Toxic wastes, whether of industrial, agricultural, or municipal origin, are being disposed of in two principal ways (National Research Council, 1983, fig. 2): (1) conversion to less hazardous or nonhazardous forms by incineration, chemical neutralization, biological alteration, industrial recycling, or dilution and (2) perpetual storage or disposal by placement in surface impoundments or landfills, injection into brine aquifers, or burial (in solid form) in thick unsaturated zones ${ }^{1}$ in arid regions. As a result of recent dramatic failures of some early landdisposal efforts-Love Canal being a prime example-considerable attention is being focused on waste conversion rather than on land-disposal methods. Yet, not all wastes are amenable to waste conversion, and some converted wastes still leave a volumetrically small, but toxic, residue requiring perpetual storage or disposal. Thick (greater than 150 m) unsaturated zones, in arid and semiarid regions, have been identified (Winograd, 1972, 1974, 1981; Wacks and others, 1981; Roseboom, 1983; Wollenburg, Yang, and Korbin, 1983; and National Research Council, 1983) as potentially favorable environments for the disposal of the most toxic of the Nation's wastes, particularly solidified high-level radioactive waste. Archaeology can make several major contributions to the evaluation and future use of thick unsaturated zones, which the National Research Council $(1983$, p. 71$)$ referred to as a "National asset in achieving a solution to the wastedisposal problem."

The unsaturated zone in many parts of the Southwestern United States exceeds $150 \mathrm{~m}$ in thickness, and zones this thick encompass a minimum volume estimated to be about $22,000 \mathrm{~km}^{3}$ (M.S. Bedinger, U.S. Geological Survey, oral commun., 1984). As a direct result of the search for sites suitable for disposal of radioactive wastes, it became apparent in the 1970's, that unsaturated zone environments had excellent potential for isolating

\footnotetext{
'The unsaturated zone is the soil and underlying rock between the land surface and the water table. In portions of the Southwest United States, such zones are hundreds of meters thick and permit burial of wastes at depths precluding exhumation by erosion.
}

solidified toxic wastes from the hydrosphere for millenia to perhaps hundreds of millenia. The attractive features of these arid and semiarid environments for waste isolation, as identified in preliminary studies (Winograd, 1972, 1974, 1981; Roseboom, 1983 ) include (1) low moisture flux, (2) high sorptive capacity of selected rocks for radionuclides, and (3) the opportunity to use natural and manmade capillary barriers and other engineering structures to divert the meager moisture flux from contacting the wastes. Potential concerns about the long-term efficacy of such environments were also identified and include (1) the potential for future human intrusion into relatively shallow burial sites, (2) the increase in recharge and rise of water table that might accompany future pluvial climates, (3) the effects of erosion and, in some areas, tectonism, and (4) the absence of detailed studies of the soil physics of such environments. Briefly, thick unsaturated zones appear very attractive for the permanent disposal of solidified toxic wastes, particularly those wastes not amenable to other treatment, because water flow, the chief pollutant-transporting mechanism, is minimal. Detailed studies of the soil physics, geochemistry, and rock mechanics of these environments are in progress at several universities; at the Sandia, Los Alamos, Lawrence Berkeley, and Livermore National Laboratories; and at the U.S. Geological Survey.

\section{EVALUATION OF PROPOSED TOXIC.WASTE REPOSITORY SITES}

Selection of new sites for disposal of the Nation's most toxic wastes, such as high-level radioactive wastes, will be a lengthy process involving detailed geotechnical investigations, numerous public hearings, and, most likely, litigation. The nature of the geotechnical work being done with regard to the disposal of high-level radioactive wastes is outlined in this section; similar studies undoubtedly will be required prior to the disposal of other types of toxic wastes.

To hedge against uncertainties, the currently accepted philosophy of radioactive-waste disposal is one of multiple barriers or, in engineering parlance, "defense in depth" (Interagency Review Group on Nuclear Waste Management, 1978). That is, a redundancy in safety is sought by using a variety of means to ensure isolation of the wastes from the hydrosphere and biosphere. In the case of high-level radioactive wastes, four barriers to radionuclide 
migration are receiving attention. The first barrier is a waste form of very low solubility, such as glass. To hedge against possible radionuclide release caused by devitrification, the waste-bearing glass may be put into a metallic or ceramic canister and even surrounded by clay or zeolite minerals. (The resulting product is referred to as a waste package.) A second major line of defense is a host rock that, ideally, contains little ground water to dissolve radionuclides from the waste package. A third line of defense is the sorptive capacity of host-rock minerals for the radionuclides; sorption can result in nuclide migration rates one to several orders of magnitude slower than the velocity of the transporting vadose ${ }^{2}$ or ground waters. The fourth line of defense is the occurrence beneath (in the case of the unsaturated zone) or within (in the case of saturated zone) the site of slowly moving ground water that is remote from points of present or likely future use. The relative importance of these barriers is, not surprisingly, highly site specific.

The ability of each of these barriers to prevent or retard radionuclide migration is undergoing extensive studies at three sites currently being evaluated for the disposal of high-level radioactive wastes: the Waste Isolation Pilot Plant site in Permian age salt beds of southeastern New Mexico, the Basalt Waste Isolation Plant site in Tertiary basalts at Hanford, Washington, and the Yucca Mountain site in unsaturated Tertiary welded tuff at the Nevada Test Site. The Materials Research Society (1984) has produced a review of some of this research. The general goals of these site studies are threefold:

(1) To obtain a detailed understanding of the numerous variables affecting the performance of each of the barriers. For example, a study of the sorption of radionuclides during movement through the host rock involves detailed knowledge of the radionuclides' rate of release from the waste form, rock mineralogy and physical properties, vadose and ground water velocity, vadose and ground water chemistry, state of the radionuclides (dissolved or colloidal and, if dissolved, their valence state), nuclide solubility, the relative importance of ion exchange, fixation, and other sorption mechanisms, and lastly the alteration of each of the above by the strong temperature and radiation fields expected in a high-level waste repository.

\footnotetext{
${ }^{2}$ Vadose waters are those occurring in the unsaturated zone.
}

(2) To quantify the observations made for each barrier by appropriate physicochemical models.

(3) To couple the quantitative models developed for each barrier into a megamodel to be used for predicting the rate of migration of radionuclides from the site and their concentration in ground and surface waters and in food chains over millenia or more (see Tyler and others, 1984; Garisto and Lyon, 1984; and Ross, 1986, for outlines of such studies).

All of these goals are formidable, but we restrict our discussion to the feasibility of the last goal, long-term prediction of the fate of radionuclides in the environment surrounding the waste repository.

A relatively small, but highly instructive, literature exists on prediction in the earth and other natural sciences. This literature may be divided into two groups: studies that examine the subject from a philosophical viewpoint and studies that emphasize the pragmatic aspects. A brief review of this literature was presented by the author and by N.J. Trask in Bredehoeft and others (1978). Study of this literature does not lead to much confidence in the ability of megamodels (or even of the component models for each barrier) to accurately predict the behavior of buried toxic wastes even over periods of a few millenia. There are three principal reasons for this. (1) An empirical data base does not exist with which to calibrate the model. Moreover, future assembly of such a data base in any reasonable time span appears to be out of the question. Calibration would require gathering of field information over a period long enough to test the processes of solution, transport, adsorption, and chemical reaction that are postulated in the models. Given the low solubilities of proposed waste forms, the accumulation of such data in the field would require decades or perhaps centuries. Thus, from the nature of the exercise, predictions of the transport and fate of these materials in the environment apparently always will be based on calculations from uncalibrated models. (2) The record of prediction in the earth sciencies, including soil mechanics, the oldest quantitative branch of earth science, is mixed. Most engineering geologic predictions, in any event, are autopsies; predictions made before the event are not as common. Papers by Lambe (1973), Peck (1980), and Leonards (1982) are particularly instructive reviews of prediction in the geotechnical sciences. (3) Strong philosophical arguments exist for believing that explanation and prediction in the natural sciences are not symmetrical; that is, understanding a process (hardly an easy undertaking) does not mean that 
prediction is attainable (Bradbury and others, 1983; Scriven, 1959; Mayr, 1961; and Simpson, 1970).

Stated in the simplest of terms, our ability to evaluate predictions of the fate of buried toxic wastes over millenia, or even centuries, is severely limited by our lack of experience. Hence, predictions of the fate of toxic wastes, whether generated by complex or by simple physicochemical models, must be viewed with great caution. Such predictions involve conditions considerably more complex than those commonly tackled in geotechnical engineering, such as estimations of the settling of a bridge or skyscraper foundation or of the drawdown of water level in a heavily stressed aquifer (Konikow and Patten, 1985). The task of predicting the long-term effects of buried toxic wastes on the hydrosphere and biosphere is an excellent example of the transscientific issues discussed by Weinberg (1985). As succinctly stated by him (1985, p. 60):

Science deals with regularities in our experience; art deals with singularities. It is no wonder that science tends to lose its predictive or even explanatory power when the phenomena it deals with are singular, irreproducible, and one of a kind - in other words, rare. Although science can often analyze a rare event after the fact - for example, the extinction of dinosaurs during the CretaceousTertiary period following the presumed collision of the earth and an asteroid-it has great difficulty predicting when such an uncommon event will occur.

What then are we to do? Certainly, process studies and modeling efforts related to understanding the fate of buried wastes must go forward, because such efforts frequently identify the weakest links in our knowledge of a system and can lead also to an early disqualification of marginal sites proposed for waste disposal. But, another endeavor is of equal importance. Synthesis of the archaeological record of man's past use of the unsaturated zone for the preservation of objects can provide an invaluable empirical data base pertinent to the transscientific problem of toxic waste disposal.

\section{POTENTIAL APPLICATIONS OF ARCHAEOLOGY TO TOXIC.WASTE DISPOSAL}

Archaeological science can contribute meaningfully to an evaluation of sites for toxic-waste disposal in three ways: (1) by addressing the general efficacy of unsaturated zones as environments suitable for isolating solidified toxic waste from the hydrosphere and biosphere over millenia to tens of millenia, (2) by addressing the issue of future human intrusion, and (3) by identifying durable, natural, and manmade objects suitable for encapsulation of wastes or for use as warning markers. The last two topics also have application to the disposal of solidified toxic wastes below the water table. The first topic-of principal concern in this paper - applies exclusively to disposal of wastes in unsaturated zones. These three topics are interrelated, but for convenience they are discussed separately here.

\section{EFFICACY OF THICK UNSATURATED-ZONE ENVIRONMENTS FOR ISOLATION OF SOLIDIFIED TOXIC WASTES}

The archaeological record of Late Paleolithic man (about 40,000-10,000 B.C.) is preserved largely in caves and rock shelters, whereas the record of Neolithic to Iron Age man (about 8000-1000 B.C.) is preserved increasingly in manmade structures. A very brief outline of this record demonstrates how well delicate, as well as durable, objects emplaced in the unsaturated zone by our ancestors - or accidentally buried in this environment-have survived over millenia to tens of millenia.

Late Paleolithic man probably was unaware that the caves that sheltered him would provide preservation of his lifestyle. Such caves, even those in the humid zone, have yielded the oldest and most famous archaeological finds (Leakey, 1981), including molded clay bison from the French cave Le Tuc d'Audoubert (about 15,000 years old), ivory animal statuettes from the German Vogelherd cave (about 32,000 years old), and the famous ice-age cave art as much as 35,000 years old. These caves provided a well-drained environment having a relatively constant annual temperature and humidity-conditions apparently favorable for preserving artifacts, despite the presence of oxidizing conditions and high humidity.

The archaeological record of Neolithic to Iron Age man contains numerous examples of preserved delicate objects that were buried, intentionally or unintentionally, in presently arid and semiarid unsaturated zones, including but not limited to cave environments. A heap of about 2,600 charred horsebean (Vicia faba L.) seeds was found in an ancient dwelling at Yiftah'el near Nazareth in Israel. The beans date from 6500 to 6000 B.C. and surprisingly were not damaged by insects (Kislev, 1985). Tenthousand-year-old wood dowel, cord, and wood batten are reported from Guitarrero Cave in Peru, where arid conditions also led to preservation of textiles and domesticated plants (Lynch and others, 1985). In areas of extreme aridity, such as along the coast of Chile, 4,000- to 8,000-year-old mummies have been discovered in shallow burial pits (Allison, 
1985). Some of these mummies were preserved naturally, whereas others show that the skills of mummification were well known to these people several thousand years before the earliest known Egyptian mummies.

Next we cite the amazing preservation of the Dead Sea scrolls placed in simple clay jars in shallow caves nearly 2,000 years ago (Pfeiffer, 1969). Nearby, at Masada, in Israel, beautifully preserved cloth, leather sandals, plaited hair, food (walnuts, dates, grain, and pomegranates), frescoes, and colored mosaic stone floors occur within a few meters of the surface; these materials date from about A.D. 70 (Yadin, 1966). These examples, only a small fraction of those known, are cited to demonstrate the amazing preservation of even delicate organic and inorganic objects placed in the unsaturated zone at shallow depths and generally without intent of preservation on the part of our ancestors. We consider next a few examples of deliberate and elaborate attempts by ancient man to preserve objects of importance.

Wacks and others (1981) briefly described several examples of the excellent preservation of a variety of objects placed within carefully designed structures built by the Egyptians, Chinese, and Indians in the period 3000 B.C. to A.D. 1000 . For example, portions of the funeral barque of Cheops (about 2600 B.C.), buried in a rectangular pit in limestone and tightly sealed by limestone blocks and gypsum, were found in excellent condition in 1954; "even a $91 \mathrm{~m}$ (300 ft.) long rope and remnants of frayed fabric were found on the top deck" (Wacks and others, 1981 , p. 9). Although the rock tombs of the New Kingdom, including that of Tutankhamen, all were ransacked, delicate objects of little value were left behind, including robes, sandals, ostrich feathers, and painted wall reliefs (Wacks and others, 1981, p. 51). In contrast, Wacks and others (1981, p. 15) reported that some of the objects in the tomb of King Tutankhamen had badly deteriorated due to periodic percolation of moisture into the tomb. The Chinese cave temples at Ch'ien-fo-tung in Kansu Province at the edge of the Gobi Desert have yielded a spectacular library of 1,000-year-old manuscript rolls, silk banners, and paintings on linen or silk gauze (Wacks and others, 1981, p. 25). Wacks and others reported the climate of Ch'ien-fo-tung to be similar to that of northern Nevada. In contrast, they found that preservation of objects was generally poor in Indian temples constructed in the basaltic Deccan Traps because of water seepage and structural weakness (Wacks and others, 1981, p. 46); these structures are all located in presently humid climates. On the basis of their brief review of these and other "time-tested underground structures," Wacks and others (1981, p. 54) concluded, as had hydrogeologists before them (Winograd, 1972, 1974), that solidified low-level radioactive wastes might be safely emplaced in a "rock-hewn waste complex" within a thick arid unsaturated zone, provided special attention were given to prevent future human intrusion.

Although not strictly in the realm of archaeology, evidence of remarkable preservation of late Pleistocene plants is available from paleoecological studies. Mummified plant fossils, in 10,000- to 45,000-year-old packrat middens, have been identified to species level (Spaulding, 1985). Such middens are found in open joint planes, small caves, and rock shelters throughout the arid and semiarid portions of the Southwestern United States. Although only marginally sheltered, the plants constituting the middens survived the relatively wetter climates of the late Pleistocene (Spaulding, 1985).

On the basis of the above cursory examination of the archaeological record, it appears that a detailed synthesis of this record-with special reference to the past and present physical setting of each site-can provide us with qualitative, yet highly pertinent, analogs of the likely long-term fate of solidified toxic wastes buried in unsaturated zone environments. Such a synthesis would seek to identify not only durable objects that have survived the tests of time but also delicate ones. It would attempt to unravel the features of the physical environment that led to excellent preservation of parchment in one cave but permitted poor preservation in an adjacent cave. It would attempt to relate preservation of delicate objects to the original and subsequent climates, as well as to the geomorphic and hydrogeologic setting of sites. The objective of such a synthesis would be no less than an attempt to understand the physical, chemical, and biological factors leading to preservation of fragile, as well as durable, objects buried in arid to semiarid (and even subhumid) unsaturated zones by Late Paleolithic to Iron Age man.

Arguments based on analogy with the archaeological record, however, contain serious problems. First, past climatic conditions at archaeological sites cannot easily be determined and probably differed from present conditions. Second, the hydrogeologic setting of the better studied archaeological sites are unlikely to match exactly those of any unsaturated zone site currently being used or being evaluated for receipt of toxic wastes. Third, unlike wastes in a high-level radioactive waste 
repository, archaeological remains were never subject to a heat pulse of several hundreds of degrees centrigrade nor to intense radiation fields. ${ }^{3}$ Lastly, archaeological records, like stratigraphic records, are incomplete. (See Ager, 1981, for a pertinent discussion of the incompleteness of stratigraphic and, by analogy, of archaeological records.) Thus the archaeological record may be biased strongly toward successful preservation, the unsuccessful ones having left no exciting finds to be described. Nevertheless, the large number of unsaturated-zone archaeological sites, their occurrence in Holocene and Pleistocene climates ranging from arid to humid, and the great variety of materials buried in them should permit us to glean a wealth of qualitative to semiquantitative information bearing on the preservation and relative weathering of materials in unsaturated-zone environments over millenia to tens of millenia. Such a synthesis can provide an independent evaluation of the efficacy of the unsaturated zone under what can be viewed only as worst-case conditions; that is, early man's burial of unshielded objects at shallow depths or his subsequent engineered emplacement of precious objects that invited repeated entry into his structures by thieves. In contrast, solidified toxic wastes of low solubility presumably will be emplaced in the unsaturated zone at depths of tens to hundreds of meters, will be encapsulated in low-solubility containers, and will be placed in burial chambers designed to conduct vadose water around the waste containers (Winograd, 1974, 1981; Roseboom, 1983).

The proposed synthesis of the archaeological record admittedly is likely to yield only qualitative information regarding the expected fate of materials buried in the unsaturated zone over millenia. Yet such a synthesis can constitute an invaluable supplement to computer-generated predictions that, although quantitative, cannot be evaluated in the absence of an empirical data base.

A second major benefit may be derived from a broad examination of the archaeological record; namely, providing the public and the courts with a readily understood basis for waste disposal in arid unsaturated zones. Public perception and acceptance are critical to any successful waste disposal program. Yet, the ability of the public and of the legal com-

\footnotetext{
${ }^{3}$ Although temperatures of 100 to several hundred degrees centigrade still appear in the high-level radioactive waste literature, current thinking (Bredehoeft and others, 1978; Swedish Nuclear Fuel Supply Co., 1983) favors keeping the temperatures well below $100^{\circ} \mathrm{C}$ to reduce anticipated thermomechanical problems in repository construction and long-term performance. For nonradioactive toxic wastes, elevated temperatures and radiation would not detract from analogies with the archaeological record.
}

munity to understand the results of interdisciplinary computer models - however well accepted they may be in the scientific community - probably is limited. And, in all likelihood, the scientific community will not be unanimous about the suitability of any single model-a not unexpected occurrence in view of the transscientific nature of the problem and a situation unlikely to lead to scientific credibility with the public. On the other hand, the public and the courts are likely to understand more readily a qualitative but strong analog approach, which a detailed examination of the archaeological record can provide. The public can nearly touch or see the archaeological record and therefore may find it more credible than computer-generated numbers of perceived mysterious origin. At the same time, the archaeological analog explicitly acknowledges one of the most serious reservations about toxic-waste disposal, especially shallow (less than 50-m-depth) disposal; namely, the potential for intrusion by our unaware descendants (see the section "Future Human Intrusion into Toxic-Waste Burial Sites").

In summary, the archaeological record examined does, in general, sustain the preliminary favorable conclusions of earth scientists regarding the utility of arid and semiarid unsaturated zones for safe burial of solidified toxic wastes. This record provides an invaluable, although qualitative, supplement to the quantitative, but untestable, computer-generated predictions of the long-term effects of buried wastes on the hydrosphere and biosphere. Once the transscientific nature of the toxic-waste disposal problem is understood, the qualitative conclusions derivable from the archaeological record may suffice to convince the public that solidified toxic waste can be safely isolated from the environment by burial in carefully chosen thick unsaturated zones. Certainly modern man should be able to equal and improve upon the practices of his ancestors in his attempt to isolate solidified toxic wastes from the environment for millenia to tens of millenia.

A detailed synthesis of the archaeological record-done by archaeologists and Quaternary geologists with toxic-waste disposal in mind-is needed to verify the generally favorable prognosis presented herein concerning the long-term isolation of solidified toxic wastes buried at depths of tens of meters in thick unsaturated zones of arid regions.

\section{FUTURE HUMAN INTRUSION INTO TOXIC-WASTE BURIAL SITES}

The potential for future human intrusion into toxic-waste burial sites has been of major concern to 
advocates of geologic disposal of radioactive wastes for more than a decade (Weinberg, 1972). Winograd (1981, p. 1462) explicitly acknowledged that of all the technical issues involved in an evaluation of thick unsaturated zones as toxic-waste repositories, "the matter of future human intrusion is the crucial unresolved and perhaps unresolvable issue." Wacks and others (1981) also were greatly concerned with intrusion. They stated $(1981$, p. 15$)$, "If the analogy between the Egyptian royal tombs and the modern nuclear burial ground is correct, simple thievery and vandalism may be more of a threat to the repository than natural phenomena such as earthquakes and floods." A site chosen for waste burial must not be associated with known ore deposits or aquifers. Given these obvious exclusions, how can we prevent future discovery of, intrusion into, and perhaps even use of the wastes by our unaware descendents? Archaeologists began to address this matter a few years ago (see, for example, papers by Cameron (1981); Kaplan (1982); and Battelle Memorial Institute (1984)). Topics studied included the geometric placement of warning markers, the languages and symbols to be used on the markers, and the endurance or physical integrity of marker materials over millenia. It can be argued that warning markers exterior to a repository will ultimately invite vandalism (and possibly intrusion) after institutional control of a site is lost and, therefore, that such markers may prove to be counterproductive. In contrast, a series of warning markers within the passages leading to the burial site or repository appear essential to warn our unaware descendents of potential danger in the case of intrusion. Additional debate on the wisdom of external markers appears in order.

The matter of the physical integrity, over millenia, of materials used for warning markers is clearly part of a third broad area in which archaeology can contribute significantly to solving the problem of toxicwaste disposal.

\section{IDENTIFICATION OF DURABLE NATURAL AND MANMADE MATERIALS}

A major research effort sponsored by the U.S. Department of Energy and its predecessors, the Energy Research Development Administration and the Atomic Energy Commission, during the 1960's and 1970's and continuing today, involves the identification of the best types of glass into which reprocessed nuclear wastes can be incorporated. ${ }^{4}$ Sought was a glass having very low solubility that would resist devitrification for millenia even when subjected to temperatures of several hundred degrees centigrade. This research, which also includes evaluation of synthetic rock, has spawned a large literature. The Materials Research Society devotes a number of symposia to this topic at its annual meetings, with the results published annually in the book series "Scientific Basis for Nuclear Waste Management" (1978-84). Relatively little attention, however, has been given to using the state of preservation of dated manmade glasses and ceramics, from the archaeological record, as clues to selection of durable materials for waste containment. Notable exceptions are the reconnaissance studies of Kaplan (1980) and Kaplan and Mendell (1982), which contrast the state of preservation of glasses of varying ages and from different climates, and the work of Roy and Langton (1983), who studied the characteristics of ancient mortars and plasters dating to 5500 B.C. Further, the geologic literature has not been fully used by wastedisposal technologists for clues regarding rates of weathering of natural glass and selected rock types. Such literature presently exists (Friedman and Long, 1976; Steen-McIntyre, 1975; and Colman and Pierce, 1981).

Clearly archaeologists, materials scientists, and Quaternary geologists should jointly study the extent of weathering of durable natural and manmade materials as a function of age, climate, geomorphichydrologic setting, and burial environment (mausolea, soil zone, colluvium, cave, rock shelter, tunnel, and so on). Additionally, detailed petrologic and geochemical studies might reveal the amounts and perhaps even rates of leaching of selected elements from dated rocks, minerals, and manmade objects buried in unsaturated (or saturated) zone environments over time frames pertinent to the isolation of toxic wastes. ${ }^{5}$ Such information would be of immediate interest to waste disposal technologists for two purposes: (1) identification of new materials into which toxic wastes might be incorporated (via solid solution) or encapsulated (that is, used to surround

\footnotetext{
${ }^{4}$ Although the disposal of spent fuel, rather than a glass waste form, has received major attention in the past 4 to 5 years, spent fuel may be placed within a waste package, the design of which can benefit from the considerations raised herein. More importantly, we are looking for time-proven materials for the encapsulation of a variety of toxic wastes.

${ }^{5}$ For example, a study contrasting the weathering of an inclined vitrophere below and above the water table at a single location could provide a wealth of information concerning relative leaching of selected elements in these two adjacent, but hydrologically different, environments.
} 
the waste, forming the so-called waste package) and (2) selection of durable rocks for fabrication into monoliths capable of marking disposal sites for millenia.

\section{SUMMARY}

A "defense in depth" approach is being used in evaluating several sites for the disposal of high-level radioactive wastes. We hope the same approach will be used in selection of new sites for land disposal of the most toxic nonradiogenic wastes. The results of laboratory and short-term field experiments on the multiple barriers at each site will be used, via interdisciplinary mathematical models, to predict the fate of buried wastes for millenia and longer. Such analyses are justifiable and challenging, but their results must be used with extreme caution in view of the limitations in geologic prediction of even far simpler systems. Clearly, the task of predicting the effects of buried toxic wastes on the environment is a transscientific one. Yet, the Late Paleolithic to Iron Age record of man's inadvertent or intentional use of the unsaturated zone for preservation of a large variety of objects can serve as an invaluable analog of the likely fate of solidified toxic wastes buried in arid and semiarid environments. The archaeological record is incomplete and qualitative, and its transference to waste disposal is subject to the limitations of all arguments by analogy. Nevertheless, it provides a real data set upon which to formulate an independent and favorable appraisal of the general ability of thick unsaturated zones in arid regions to isolate solidified toxic wastes from the hydrosphere and biosphere for millenia and beyond. Moreover, such an appraisal probably can be comprehended far more easily by the public and by the courts than the numerical output of sophisticated interdisciplinary models of the fate of buried toxic waste. Archaeological science can make substantial contributions also to the related important matters of preventing future human intrusion into toxic-waste burial sites, choice of solids in which toxic wastes can be incorporated or encapsulated, and choice of rocks from which durable warning markers can be constructed.

Archaeologists can contribute substantially to evaluation of arid and semiarid unsaturated zone sites proposed for the disposal of solidified toxic wastes. The involvement of archaeologists in such studies, together with earth scientists, chemical engineers, and other scientists, appears mandatory.

\section{ACKNOWLEDGMENTS}

I thank E-an Zen and Newell J. Trask for informal reviews of an early draft and Gordon B. Bennett, George A. Dinwiddie, Curtis E. Larsen, James R. Rollo, and E-an Zen for helpful suggestions pertinent to the final draft. This paper is an outgrowth of talks given in January 1984 and January 1986 at University of Arizona workshops on the physics and chemistry of contaminant transport through the unsaturated zone. I thank Professor James G. McCray for calling my attention, during the first workshop, to an important paper by Wacks and others (1981) that clearly recognized the potential utility of archaeology in selecting sites for the disposal of low-level radioactive wastes.

\section{REFERENCES CITED}

Ager, D.V., 1981, The nature of the stratigraphic record ( $2 \mathrm{~d}$ ed.): New York, John Wiley, $122 \mathrm{p}$.

Allison, M.J., 1985, Chile's ancient mummies: Natural History, v. 94 , no. 10 , p. $74-81$.

Battelle Memorial Institute, 1984, Reducing the likelihood of future human activities that could affect geologic high-level waste repositories: Office of Nuclear Waste Isolation, Battelle Memorial Institute Report BMI/ONWI-537, 129 p.

Bradbury, R.H., Hammond, L.S., Reicheu, R.E., and Young, P.C., 1983, Prediction versus explanation in environmental impact assessment: Search, v. 14, p 323-235 [Discussion by I.R. Kennedy in v. 15, p. 219-222].

Bredehoeft, J.D., England, A.W., Stewart, D.B., Trask, N.J., and Winograd, I.J., 1978, Geologic disposal of high-level radioactive wastes-Earth-Science Perspectives: U.S. Geological Survey Circular 779, $15 \mathrm{p}$.

Cameron, F.X., 1981, Human intrusion into geologic repositories for high-level radioactive waste-Potential and prevention: Radioactive Waste Management, v. 2, no. 2, p. 179-187.

Colman, S.M., and Pierce, K.L., 1981, Weathering rinds on andesitic and basaltic stones as a Quaternary age indicator, Western United States: U.S. Geological Survey Professional Paper 1210, 56 p.

Friedman, Irving, and Long, William, 1976, Hydration rate of obsidian: Science, v. 191, no. 4225 p. 347-352.

Garisto, N.C., and Lyon, R.B., 1984, Environmental modelling and geologic disposal of nuclear fuel waste, in Fleet, M.E., ed., Short Course in Environmental Geochemistry: Mineralogic Association of Canada, Short Course Handbook, v. 10. ch. 9, p. 217-235.

Interagency Review Group on Nuclear Waste Management, 1978, Isolation of radioactive wastes in geologic repositories: Status of scientific and technological knowledge, in Alternative technology strategies for the isolation of nuclear waste: $\mathrm{Na}$ tional Technical Information Services Report TID-28818 (Draft), Appendix A, 89 p.

Kaplan, M.F., 1980, Characterization of weathered glass by analyzing ancient artifacts; in Northrup, C.J.M., Jr., ed., Scientific basis for nuclear waste management, vol. II: New York, Plenum Press, p. 85-92. 
1982, Archaeological data as a basis for repository marker design: Office of Nuclear Waste Isolation Report ONWI$3541,92 \mathrm{p}$.

Kaplan, M.F., and Mendel, J.E., 1982, Ancient glass and the safe disposal of nuclear waste: Archaeology, v. 35, no. 4, p. 22-29.

Kislev, M.E., 1985, Early Neolithic horsebean from Yiftah'el, Israel: Science: v. 228 , no. 4697 p. 319-320.

Konikow, L.F., and Patten, E.P., Jr., 1985, Groundwater forecasting, in Anderson, M.G., and Burt, T.P., eds. Hydrological forecasting: New York, John Wiley, ch. 9, p. 221-270.

Lambe, T.W., 1973, Predictions in soil engineering: Geotechnique, v. 23 , no. 2 , p. 149-202.

Leaky, R.E., 1981, The making of mankind: New York, E.P. Dutton, $256 \mathrm{p}$.

Leonards, G.A., 1982, Investigation of failures: Journal of Geotechnical Engineering Division, American Society of Civil Engineering, ASCE, v. 108, no. GT2, p. 187-246.

Lynch, T.F., Gillespie, R., Gowlett, J.A.J., and Hedges, R.E.M., 1985, Chronology of Guitarrero Cave, Peru: Science, v. 229, no. 4716 p. 864-867.

Materials Research Society, 1978-84, Scientific basis for nuclear waste management: New York, Plenum Press and NorthHolland Press, v. I - VII.

Mayr, Ernest, 1961, Cause and effect in biology: Science, v. 134, p. 1501-1506.

National Research Council, 1983, Management of hazardous industrial wastes - Research and development needs: National Materials Advisory Board, National Academy Press Publication NMAB-398, $76 \mathrm{p}$

Peck, R.B., 1980, "Where has all the judgment gone," The fifth Laurits Bjerrum memorial lecture: Canadian Geotechnical Journal, v. 17, no. 4, p. 584-590.

Pfeiffer, C.F., 1969, The Dead Sea Scolls and the Bible: New York, Weathervane Books, 152 p.

Roseboom, E.H., Jr., 1983, Disposal of high-level nuclear waste above the water table in arid regions: U.S. Geological Survey Circular 903, $21 \mathrm{p}$.

Ross, B., 1986, Scenarios in performance assessment of highlevel waste repositories: Radioactive Waste Management and the Nuclear Fuel cycle, v. 7, no. 1, p 47-61.

Roy, D.M., and Langton, C.A., 1983, Characterization of cementbased ancient building materials in support of repository seal materials studies: Office of Nuclear Waste Isolation, Battelle Memorial Institute Report BMI/ONWI-523.

Scriven, Michael, 1959, Explanation and prediction in evolutionary theory: Science: v. 130 , no. 3374 , p. $477-482$.
Simpson, G.G., 1970, Uniformitarianism: An inquiry into principle, theory, and method in geohistory and biohistory, in Hecht, M.K., and Steere, W.C., eds., Essays in evolution and genetics in honor of Theodosius Dobzhansky: New York, Appleton-Century-Crofts, p. 43-96.

Spaulding, W.G., 1985, Vegetation and climates of the last 45,000 years in the vicinity of the Nevada Test Site, south-central Nevada: U.S. Geological Survey, Professional Paper 1329, $83 \mathrm{p}$.

Steen-McIntyre, Virginia, 1975, Hydration and superhydration of tephra glass - A potential tool for estimating age of Holocene and Pleistocene ash beds, in Suggate, R.P., and Cresswell, M.M., eds., Quaternary studies: Wellington, Royal Society of New Zealand, p. 271-278.

Swedish Nuclear Fuel Supply Co./Division KBS, 1983, Final storage of spent nuclear fuel KBS-3: Swedish Nuclear Fuel Supply Co./Division KBS, ch. 1, p. 4.17-4.19.

Tyler, L.D., Peters, R.R., Hayden, N.K., Johnstone, J.K., and Sinnock, S., 1984, NNWSI performance assessment considerations, in McVay, G.L., ed., Scientific basis for nuclear waste management, vol. VII: New York, North-Holland Press p. 327-344.

Wacks, M.E., Kuck, P.H., Matloubieh, A.Y., and McCray, J.G., 1981, Time-tested underground structures suitable for isolating low-level waste: Engineering Experiment Station, University of Arizona report prepared for the Los Alamos Scientific Laboratory under Contract 4-N-20-0328N-1, 56 p.

Weinberg, A.M., 1972, Social institutions and nuclear energy: Science, v. 177, p. 27-34.

1985, Science and its limits - The regulator's dilemma: Issues in Science and Technology, v. 2, no. 1, p. 59-72.

Winograd, I.J., 1972, Near surface storage of solidified high-level wastes in thick (400-2,000 feet) unsaturated zones in the Southwest: Geological Society of America, Abstracts with Programs, v. 4, no. 7, p. 708-709.

1974, Radioactive waste storage in the arid zone: Eos, Transactions American Geophysical Union, v. 55, no. 10, p. 884-894 [Discussion in v. 57, no. 4, p. 178, 215-216].

1981, Radioactive waste disposal in thick unsaturated zones: Science, v. 212, no. 4502, p. 1457-1464 [Discussion in v. 215, p. 914].

Wollenberg, H.A., Yang, J.S.Y., and Korbin, G., 1983, An appraisal of nuclear waste isolation in the vadose zone in arid and semi-arid regions: Lawrence Berkeley Laboratory Report LBL-15010, $126 \mathrm{p}$.

Yadin, Y., 1966, Masada: New York, Random House, 272 p. 


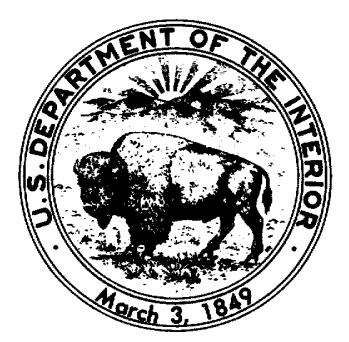

